\title{
PERNIKAHAN DINI DI KOTA YOGYAKARTA DITINJAU DARI ASPEK PENDIDIKAN AGAMA
}

\section{EARLY MARRIAGE IN YOGYAKARTA CITY IS REVIEWED FROM RELIGIOUS EDUCATION ASPECTS}

\author{
Hanif Cahyo Adi Kistoro \\ Universitas Ahmad Dahlan Yogyakarta \\ Jl. Gabus 1 No. 18 Minomartani Ngaglik Sleman Yogyakarta \\ hanif.kistoro@pai.uad.ac.id \\ Fauzi Sulaeman \\ Universitas Ahmad Dahlan Yogyakarta \\ Fauzisulaeman94@gmail.com
}

Naskah diterima tanggal 13 Juli 2019, Naskah direvisi tanggal 8 Agustus 2019, Naskah disetujui tanggal 29 Oktober 2019

\begin{abstract}
Abstrak
Fenomena pernikahan dini saat ini marak terjadi di berbagai tempat. Pernikahan dini muncul karena ada faktor pemicunya. Salah satu faktor utama dalam pernikahan dini adalah adanya kasus kehamilan pra nikah. Kasus ini banyak terjadi karena kurangnya pengetahuan tentang pendidikan. Selain faktor pendidikan. Kurangnya pengetahuan dan informasi tidak cukup membantu dalam mengarungi bahtera rumah tangga. Ketidaksiapan dari aspek mental, ekonomi, status sosial berdampak pada keberlangsungan pernikahan dini. Akibatnya banyak terjadi perceraian dini diantara pasangan pernikahan dini. Penelitian ini adalah penelitian kualitatif dengan teknik analisis deskriptif analitis, yakni memberikan atau uraian tentang fenomena, pandangan tokoh pendidikan islam, faktor, dan sisi positif negatif dari perkawinan dini. Subyek penelitian di tentukan dengan teknik purposive sampling, dimana informan sudah ditentukan dengan sengaja berdasarkan lokasi tertentu yaitu daerah Kota Gede Yogyakarta dengan jumlah partisipan 7 orang. Pengumpulan data dilakukan dengan metode wawancara, observasi, dokumentasi dan pengumpulan literatur sesuai tema penelitian. Berdasarkan hasil analisis dan temuan dapat disimpulkan bahwa fenomena pernikahan dini di daerah Yogyakarta ternyata di sebabkan karena faktor rendahnya tingkat pendidikan, minimnya wawasan agama, dan pergaulan sosial yang sangat bebas. Pasangan pernikahan dini, tidak banyak mengetahui sebelumnya tentang batasan dalam pergaulan dan perkawinan. Hal ini juga disebabkan karena faktor pendidikan yang rendah. Rata - rata berpendidikan SD dan SMP. Dengan bekal pendidikan yang masih kurang sudah tentu mereka tidak dapat berpikir secara komprehensip tentang adanya pernikahan. Pernikahan dilangsungkan karena keterpaksaan.
\end{abstract}

kata kunci: pernikahan dini, pendidikan agama, yogyakarta.

\begin{abstract}
The phenomenon of early marriage us currently fife in various places. Early marriage arises because there is a trigger factor. In of the main factors in early marriage is the case of premarital pregnancy. This case happens a lot because of lack of knowledge about education. Besides education factors. Lack of knowledge and information is not enough to help navigate the household ark. The unpreparedness of the mental aspect. Economic, social status affects the continuity of early marriage. As result early divorces occur between early marriage couples. This research is qualitative research with analytical descriptive analysis technique, which gives or describes a phenomenon, the views of Islamic education figures, factors, and the positive and negative sides of early marriage. The research subjects were determined by purposive sampling technique, where the informant was determined intentionally based on a specific location that is the big city of Yogyakarta with 6 participants. Data collection is done by interview, observation and documentation and literature collection according to the research theme. Based on the results of the analysis and findings it can be conclude that the
\end{abstract}

Pernikahan Dini di Yogyakarta Ditinjau dari Aspek Pendidikan Agama - Hanif Cahyo Adi Kistoro dan Fauzi Sulaeman 431 
phenomenon of early marriage in the Yogyakarta area was apparently caused by the factor of low levels of education, lack of religious insight, and very free social relations. Early marriage partners don't know much in advance about the limitations of relationships and marriage. This is also due to the low education factor. Most of them have elementary and junior hight school education. With the lack of education they certainly cannot think comprehensively about the existence of marriage. Marriage takes place because of compulsion.

keywords: early marriage, religious education, Yogyakarta.

\section{PENDAHULUAN}

$\mathrm{S}$ ebuah perkawinan merupakan ikatan suci antara sepasang laki-laki dan wanita yang mempunyai keinginan bersama untuk membentuk sebuah bangunan rumah tangga dalam mengarungi kehidupannya. Adanya ikatan perkawinan tentu didasari rasa saling memahami dan mengasihi serta sudah mempunyai ketentuan syarat baik dari aspek agama ataupun aspek hukum negara.

Kehidupan suami istri dalam tuntunan hukum Islam harus ditegakkan di atas dasar kerukunan, cinta dan kasih sayang serta pembentukan kerukunan yang baik. Untuk mendapatkan kerukunan yang baik dalam rumah tanggga maka harus ada persiapan yang matang, baik dari segi fisik maupun mental serta usaha kedua calon suami istri. Hal ini sesuai dengan hadits Nabi Muhammad SAW:

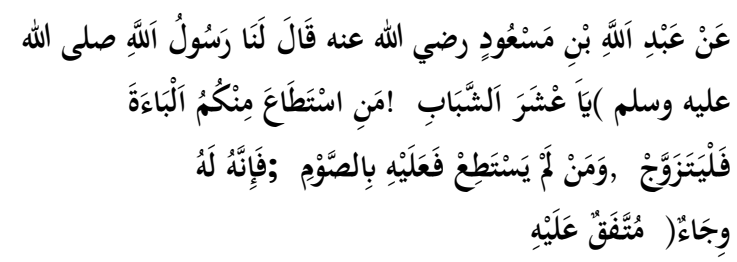

Artinya "Dari Abdullah Bin Mas'ud ra ia berkata: Rasulullah bersabda, wahai (generasi) pemuda, barang siapa diantara kalian sudah siap atau mampu berumah tangga, maka kawinlah sesungguhnya kawin itu dapat menjaga pandangan mata dan memelihara kemaluan dari (perbuatan maksiat). Barang siapa yang belum mampu hendaklah ia berpuasa itulah dirinya akan telindungi dari kemaksiatan." (HR. Bukhari Muslim)).

Pengertian siap dan mampu dalam hadis diatas dimaknai sebagai syarat dalam menjalankan pernikahan. Bentuk kesiapan dan kemampuan di tekankan pada aspek kesiapan usia, bekal pengetahuan dan ekonomi. Usia yang telah dianggap cukup dan matang, pendidikan yang tinggi dan mempunya tingkat kemampuan ekonomi yang cukup akan berpengaruh terhadap kemampuan pasangan suami istri untuk berpikir jernih, visoner dan tidak mengambil keputusan tanpa pertimbangan.

Ditambahan dalam Undang-undang No. I Tahun 1974 Bab I Pasal I di sebutkan juga bahwa: "Perkawinan adalah ikatan lahir batin antara seorang pria dan seorang wanita sebagai suami istri dengan tujuan membentuk keluarga (rumah tangga) yang bahagia dan kekal berdasarkan ketuhanan Yang Maha Esa"

Berdasarkan hadits di atas dan pengertian perkawinan menurut undangundang perkawinan maka dapat dipahami bahwa tujuan pernikahan adalah membentuk keluarga bahagia dan kekal berdasarkan ketuhanan yang Maha Esa. Dan kebahagiaan rumah tangga yang dimaksud disini salah satu cirinya adalah terbentuknya keluarga Syakinah Mawaddah Warahmah yang didalamnya ada rasa kasih sayang maka akan menjadikan keluarga itu bahagia. Terjadinya suatu pernikahan yang terlalu dini, maka hal tersebut kurang mendukung terbentuknya keluarga bahagia dan sejahtera (Sudarsono, 1992, p. 9), menambahkan bahwa, tujuan dari perkawinan adalah untuk membentuk keluarga yang bahagia dan kekal. Untuk itu suami istri perlu saling membantu dan melengkapi, agar masing-masing dapat mengembangkan kepribadiannya membantu dan mencapai kesejahteraan spritual dan materiil.

Islam sebagai sebuah ajaran yang lengkap memiliki pandangan tersendiri tentang pernikahan. Pernikahan adalah cara untuk membangun keluarga islami yang mulia, serta cara untuk memakmurkan dunia dengan keturunan dan anak shaleh yang menjamin berkesinambungannya kehidupan di permukaan planet bumi ini. Itulah tujuan yang di kehendaki Allah SWT dari penciptaan lakilaki dan perempuan. Allah Ta'ala. Menjadikan 
manusia itu saling mengetahui antara satu sama lain, sehingga bangunan masyarakat menjadi sempurna dan roda kehidupan berlanjut dengan karunia sebagai patron menjadi manusia yang bertanggung jawab.

Dengan keagungan dan kebesaran Allah SWT, dijadikanlah perkawinan bermula dari dorongan insting dan syahwat seksual untuk tujuan kelestarian manusia (regenerasi), tidak membiarkan pernikahan terwujud hanya lantaran keinginan manusia semata. Bersamaan dengan tercukupinya kebutuhan biologis, seseorang muslim pun akan meraih Ridho Allah SWT. Sebab, telah mewujudkan tujuan pencipta alam semesta, yakni agar dunia makmur dengan generasi Sholeh yang beribadah hanya kepada Allah SWT. Menegakkan kebenaran dan keadilan, serta mewujudkan khalifah di muka bumi . Seperti dijelaskan dalam Al Quran, Q.S Al-Baqoroh ayat 30 (Agama RI, 2010): Dan (ingatlah) tatkala Tuhan engkau berkata kepada Malaikat: Sesungguhnya Aku hendak menjadikan di bumi seorang khalifah.

Berdasarkan ayat diatas salah satu tujuannya adalah kelestarian kehidupan manusia. Oleh sebab itu secara fitrah, Allah SWT telah menganugerahkan sebuah sifat manusia saling tertarik antara laki - laki dan perempuan. Ketertarikan ini memunculkan rasa cinta dan kasih sayang. Islam telah mengatur dan memerintahkan manusia untuk menyalurkan cintanya dalam bentuk pernikahan yang halal dan menghalalkan. Maka Islam hadir dengan memberikan solusi untuk memenuhi kebutuhan tersebut maka dengan cara kawin dan tidak melakukan sesuatu perbuatan yang dilarang agama seperi misalnya perzinaan (Burhan, 2005, p. 35).

Di era saat ini yang interaksi hubungan satu orang dengan orang lain sudah semakin mudah dan bebas, ternyata berdampak terhadap paradigma pemikiran dan proses terjadinya pernikahan. Banyak kasus munculnya pernikahan dini di kalangan remaja karena munculnya kebebasan pergaulan ini. Gejala ini tidak hanya melanda kota - kota besar, tetapi di beberapa daerah lainnya.

Berdasarkan data yang ada, pernikahan anak usia dini angkanya makin meningkat setiap tahunnya. Dari laporan
UNICEF dan Badan Pusat Statistik (BPS) sampai tahun 2018, tercatat ada 1.000 anak perempuan yang menikah setiap harinya. Di Yogyakarta sendiri, sebagai salah satu kota yang banyak populasi penduduknya, juga banyak terjadi pernikahan dini. Pada tahun 2018, tercatat ada 312 dispensasi pernikahan dini oleh pengadilan agama DIY. Angka ini meningkat dari tahun 2017 yang hanya berada diangka 294 dispensasi. Faktor adanya pernikahan dini diantaranya karena kehamilan pra nikah, kemiskinan (ekonomi) dan budaya. Pengadilan Agama DIY maupun kabupaten/kota "terpaksa" mengizinkan pasangan usia dini menikah karena sudah hamil. Padahal Undang-undang nomor 1/1974 tentang Perkawinan, disebutkan batas minimal usia menikah perempuan 16 tahun dan lakilaki 19 tahun (Suara Muhammadiyah, 2019, p. 9).

Adanya peningkatan jumlah pernikahan dini di kalangan remaja yang memiliki kecenderungan naik dari tahun ke tahun jelas menjadi persoalan tersendiri bagi pemerintah daerah khususnya di DIY. Efek lain dari pernikahan dini ini ternyata juga menimbulkan masalah baru yaitu munculnya kecenderungan perceraian yang tinggi di kalangan remaja tersebut. Sesuai dengan pengamatan di lapangan, gejala pernikahan dini dan perceraian ini terjadi karena belum siapnya mereka menjalani rumah tangga. Usia yang masih muda, pendidikan yang rendah baik pendidikan formal ataupun agama, penghasilan ekonomi yang belum mapan mempengaruhi cara berpikir dan bertindak serta dalam pengambilan keputusan. Selain itu faktor munculnya pernikahan dini juga tidak terlepas dari adanya model pergaulan bebas dikalangan remaja. Belum mampunya tingkat pemahaman dan pengetahuan mereka serta kecenderungan untuk mencoba sesuatu tanpa memikirkan akibatnya juga menjadi alasan munculnya gejala ini.

Berdasarkan fenomena diatas, ada sesuatu yang menarik dengan adanya pernikahan dini yang tinggi di daerah Yogyakarta. Pernikahan dini muncul karena beberapa faktor, diantaranya kehamilan pra nikah, faktor ekonomi, faktor budaya. Ada faktor lain yang coba diteliti dengan 
munculnya fenomena pernikahan dini di Yogyakarta yaitu dari aspek pendidikan agama khususnya pendidikan agama ISLAM. Pasangan yang melakukan pernikahan dini apakah sudah mendapatkan bekal yang cukup dalam materi pendidikan agama sebagai salah satu bekal dalam persiapan membina rumah tangga.

Tujuan penelitian ini, ingin mengetahui dan mencari sebab munculnya pernikahan dini yang terjadi dikalangan remaja di DIY. Adapun manfaat dari penelitian ini dapat menjadi panduan bagi orang tua dan masyarakat dalam memberikan pemahaman tentang pentingnya pentingnya pendidikan baik secara formal dan agama bagi anaknya. Selaian itu penelitian ini juga memberikan gambaran tentang upaya preventif atau pencegahan dalam pergaulan remaja. Pertanyaan penelitian yang akan diajukan adalah apakah pasangan yang melakukan pernikahan dini sudah mendapatkan pendidikan agama yang cukup. Penelitian ini akan mencoba mendiskripsikan bagaimana pendidikan agama hubungannya dengan tingkat pernikahan dini yang muncul.

\section{Tinjauan Pustaka}

\section{Perkawinan}

Perkawinan merupakan kegiatan sakral dan suci yang di lakukan untuk membentuk mahligai rumah tangga. Perkawinan berasal dari kata "kawin" yang menurut bahasa artinya membentuk keluarga dengan lawan jenis, melakukan hubungan kelamin atau bersetubuh (Ghazaly, 2003, p. 7). Perkawinan disebut juga "pernikahan", berasal dari kata nikah yang menutur bahasa artinya mengumpulkan saling memasukan, dan digunakan arti bersetubuh (Wathi). Kata nikah sendiri sering dipergunakan untuk arti persetubuhan coitus, juga arti akad nikah.

Pernikahan bukanlah sesuatu yang ditakuti dan bukan pula sebuah perkara yang harus diremehkan oleh manusia (Wahyudi, 2010, p. 12). Karena pernikahan adalah fitrah manusia yang sejalan dengan syariat Allah SWT dan sunnah Rasul-Nya SAW yang disebutkan dalam Hadits yang berbunyi "Sungguh diantara sunnahku itu nikah". Akan tetapi persiapan yang matang dalam memasuki dunia pernikahan harus diperhatikan dan didahulukan dengan berbagai kemantapan. Dimana pernikahan adalah merupakan masa yang penuh dengan tantangan untuk mengaktualisasikan nilai-nilai kepemimpinan dalam rumah tangga.

Menurut Junaedi, kata nikah atau ziwaj adalah bahasa Arab yang dalam bahasa Indonesia diartikan "kawin". Sedangkan menurut istilah yang disepakati, nikah atau perkawinan adalah akad nikah yang ditetapkan oleh syara bahwa seorang suami dapat memanfaatkan dan bersenang-senang dengan kehormatan/kemaluan seorang istri dan seluruh tubuhnya. Nikah (kawin) menurut arti aslinya ialah hubungan seksual tetapi menurut majazi (methaporic) atau arti hukum ialah akad sepasang suami isti atau seorang pria dan sesorang wanita (Ramulyo, 2002, p. 1).

Secara umum pengertian perkawinan dini adalah perkawinan yang dilangsungkan saat remaja, belum atau baru saja berakhir. Menurut WHO, batas usia remaja adalah 1224 tahun. Sedangkan menurut Departemen kesehatan, rentang usianya 10-19 tahun (dengan catatan belum kawin). Dan menurut Direktorat Remaja dan Perlindungan Hak Reproduksi BKKBN, batasannya 10-12 tahun.

Perkawinan dianggap sah apabila dilakukan menurut hukum masing-masing agamanya dan kepercayaannya. Kemudian ada beberapa hal yang perlu diketahui tentang perkawinan yang dapat dilihat dari segi hukum, sosial, dan agama. Dari segi hukum, perkawinan merupakan suatu perjanjian. Perkawinan diartikan sebagai bentuk perjanjian karena cara akad nikah dan rukun atau syarat tertentu, cara menguraikan atau memutuskan ikatan perkawinan juga telah diatur sebelumnya yaitu dengan prosedur talak, kemungkinan fasakh, syiqaq dan sebagainya.

Perjanjian dalam perkawinan ini mengandung tiga karakter khusus, pertama, perkawinan tidak dapat dilakukan tanpa unsur sukarela dari kedua belah pihak. Kedua, pasangan yang mengikat persetujuan perkawinan itu saling mempunyai hak untuk memutuskan perjanjian tersebut berdasarkan ketentuan yang sudah ada hukum-hukumnya. 
Ketiga, persetujuan perkawinan iu mengatur batas-batas hukum mengenai hak dan kewajiban masing-masing pihak.

Dari segi sosial, perkawinan dipandang sebagai sebuah prosesi yang dengannya dapat meningkatkan derajat seseorang. Dalam kehidupan bermasyarakat khususnya budaya Timur, seseorang yang kawin akan cenderung dinilai secara berbeda (lebih dihargai). Dari segi agama, perkawinan itu dianggap suatu perjanjian yang suci. Upacaranya pun dianggap upacara suci. Dalam sebuah agama umumnya upacara perkawinan memiliki aturan tatacara tersendiri dengan melibatkan unsur ilahiah di dalamnya seperti mengucapkan nama Tuhan saat berlangsungnya akad (Ramulyo, 2002, p. 16).

\section{Usia dini}

Menurut (Muhammad Masngudi, 2017) usia dini adalah kata yang berkaitan dengan waktu diartikan awal waktu, sedangkan yang dimaksud dengan pernikahan usia dini adalah pernikahan yang dilakukan dibawah usia yang seharusnya serta belum siap dan matang untuk melaksankan pernikahan dan menjalani kehidupan rumah tangga ( $M$ Masngudi, 2017, p. 15).

\section{Pendidikan Agama}

Esensi pendidikan agama adalah pendidikan yang dapat menembus hati nurani anak, mengembangkan semangat keagamaan, mengikat segi-segi kepribadian anak dengan akidah dan ajaran-ajaran spiritual, memperkuat hubungan dengan Allah, dengan cara mengakrabkan anak dengan Al-qur'an untuk dihafal, dipahami dan dipelajari, dan juga pada sunnah dan Rosul, sirah sahabat, sirah thabi'in, dan sirah orang-orang yang saleh (Mahfudz, 2001, p. 184)

Pendidikan merupakan hal yang sangat mendasar dalam kehidupan manusia, karena melalui pendidikanlah manusia akan dapat membedakan antara yang baik dan yang buruk, dengan pendidikan harapan manusia dapat merasakan kebahagiaan lahir dan batin dalam kehidupanya dan dengan pendidikan pulalah diharapkan manusia menjadi dewasa lahir dan bathin.
"Pendidikan adalah bimbingan atau pimpinan secara sadar oleh sipendidik terhadap perkembangan jasmani dan rohani siterdidik menuju terbentuknya kepribadian yang utama."(Marimba, 1992, p. 20)

Dari kutipan di atas dapatlah diambil suatu pengertian bahwa pendidikan adalah upaya secara sadar oleh pendidik terhadap anak didik dalam membentuk kepribadian anak didik, pribadi yang utama dapat diartikan sebagai pribadi yang baik, unggul dalam segala hal, dan mampu menghadapi hidup secara realisasi serta mampu mengatasi segala masalah yang dihadapinya, begitu juga hendaknya ketika dia kawin dan memasuki rumah tangga, dalam rangka memenuhi sunnah Rosul.

\section{METODE PENELITIAN}

Penelitian ini adalah penelitian kualitatif dengan teknik analisis deskriptif analitis, yakni memberikan atau uraian tentang fenomena (Sugiyono, 2015, p. 15). Pandangan tokoh pendidikan Islam, faktor, dan sisi positif negatif dari perkawinan dini. Data-data yang ada kemudian dianalisis sehingga menemukan sebuah kesimpulan. Subyek penelitian di tentukan dengan teknik purposive sampling, dimana informan sudah ditentukan dengan sengaja berdasarkan lokasi tertentu yaitu daerah kota gede Yogyakarta. Pengumpulan data dilakukan dengan metode wawancara, observasi, dokumentasi dan pengumpulan literatur sesuai tema penelitian .

Sumber informasi didapatkan dari wawancara dengan informan utama yaitu pasangan suami atau istri yang melakukan pernikahan dini, pihak KUA, ketua RT yang berada di wilayah kota yogyakarta. Sementara Observasi ini dilakukan untuk mengetahui proses bagaimana perkawinan dini berlangsung di KUA, dan mengetahui syaratsyarat yang dilaksanakan kepada pasangan perkawinan dini. Data dokumentasi diambil sebagai data sekunder dalam bentuk dokumen perkawinan, seperti buku nikah pasangan perkawinan dini, surat dispensasi yang dikeluarkan oleh pengadilan agama, dan data pendaftaran perkawinan dini di KUA. 
Teknik analisis data dilakukan dengan tahap mengumpulkan data, mereduksi data, memaparkan hasil dan memberikan analisis data dan terakhir menyimpulkan berdasarkan temuan yang didapatkan (Creswell, 2015, p. 250).

\section{PEMBAHASAN}

\section{Fenomena Perkawinan Dini Di Kota Yogyakarta}

Dalam perkawinan, salah satu target yang mendasar adalah bagaimana menciptakan keharmonisan, kerukunan dan kebahagiaan dalam rumah tangga dengan puncak kebahagiaan yang sesungguhnya. Namun hanya sedikit yang mengerti tentang arti bahagia dalam perkawinan. Perkawinan bahagia merupakan idaman bagi setiap orang, bahkan menjadi simbol keberhasilan dalam kehidupan rumah tangga. Tidak sedikit manusia yang mengorbankan segala-galanya untuk meraihnya. Dan berusaha menggantungkan cita-cita menjulang setinggi langit dengan puncak untuk mencapai perkawinan yang bahagia.

Berdasarkan hasil wawancara dengan (Supriyono, 2019) kepala KUA kota gede, pada dasarnya, pasangan perkawinan dini di Yogyakarta terjadi karena adanya hamil diluar nikah. Pernikahan ini terjadi pada rentang usia 15- 18 tahun. Di usia yang masih muda mereka tentu belum siap dengan segala konsekuensi dari munculnya pernikahan dini. Kesiapan mental (psikis) dan ekonomi juga menjadi kendala dalam mengarungi pernikahan. Sehingga banyak yang kemudian terjadi perceraian yang tinggi pula. Statistik adanya pernikahan dini dapat dilihat dari table 1 . berikut:

\begin{tabular}{|l|l|l|}
\hline Inisial & Tingkatan Sekolah & Usia perkawinan \\
\hline MAS & SLTP & 15 tahun \\
\hline MDM & SLTP & 15 tahun \\
\hline ATM & SLTP & 16 tahun \\
\hline TDS & SLTP & 16 tahun \\
\hline YLT & SLTP & 17 tahun \\
\hline RES & SD & 16 tahun \\
\hline ER & SD & 18 tahun \\
\hline
\end{tabular}

Table 1. pernikahan dini berdasarkan usia dan tingkat pendidikan. Sumber : KUA Kota Gede Yogyakarta tahun 2019
Berdasarkan tabel di atas dapat dilihat bahwa dengan usia yang begitu muda dan tingkat pendidikan yang rendah akan berdampak pada kesiapan mental, kestabilan emosi dan kemampuan mengambil keputusan yang berhubungan dengan keberlangsungan pernikahan.

\section{Pandangan Tokoh-Tokoh Pendidikan Islam Terhadap Perkawinan Dini}

Tantangan kehidupan keluarga itu bukan sekedar bertemunya laki-laki dan perempuan, tetapi banyak faktor tantangannya. Memadukan dua orang yang berbeda untuk kepentingan misi ilahiah, misi bahwa menikah memerlukan cara berfikir, jiwa, kemudian juga tindakan dewasa. Selain itu, organ masih muda juga belum mencukupi untuk bisa bertanggung jawab di masa-masa berkeluarga. Untuk itu perlu kesiapan mental dan pengetahuan dalam mengarunginya.

Salah satu hal penting dalam persiapan pernikahan adalah faktor usia. Usia yang benar - benar cukup sebagai bekal di sarankan setelah 20 tahun keatas. Pada usia ini diyakini kesiapan secara lahir dan batin sudah dianggap cukup. Dari sisi mental, pikiran, pengetahuan, punya rasa tanggung jawab, juga organnya sudah semakin kuat (Suara Muhammadiyah, 2019, p. 11).

Selain itu pendidikan juga perlu dibekali supaya calon pasangan mempunyai kemampuan dalam berpikir dan mencari solusi permasalahan yang nantinya timbul dari adanya pernikahan. Pendidikan agama salah satu merupakan faktor terpenting.

Untuk menguatkan dalam pembahasan penelitian ini ada beberapa tokoh dalam dunia pendidikan yang diminta pendapatnya tentang fenomena pernikahan dini di Yogyakarta.

Tokoh masyarakat (Wahyu, 2019) berpendapat bahwa, Pandangan Islam membahas tentang perkawinan dini, ada mudharat. Agama melarang kemudharatan. Kalau perkawinan dini, sacara umum tidak siap, mental tidak siap, intelektual tidak siap. Itu akan menjdaikan sebab perceraian. Padahal cerai itu dibenci. Boleh dilakukan, tetapi tidak disukai Allah. Perkawinan harus menjaga martabat perempua, anak, dan keturunan. 
Kalau seseorang menikahi pasanganya, itu sesungguhnya dia mencatatkan kebudayaan di lingkungannya, di lingkup terkecil yang ada di sekitarnya. kalau tidak sama-sama, itu susah.

Tujuan menikah menggunakan dasar QS Ar-Rum ayat 22 adalah mengapai keluarga sakinah. Perlu proses adaptasi. Sakinah akan hadir dengan dua syarat: mawadah dan warahmah, harus ada cinta dan kasih sayang. Kalo mawadah itu cinta karna tarikan fisik. Rahmah itu cinta yang disertai rasa welas asih. Kasihan pasangannya tidak bisa melakukan sesuatu, maka diingatkan, dibantu diberdayakan.

Sementara tokoh (Surahman, 2019), berpendapat bahwa dalam persoalan perkawinan dini menjelaskan dalam ajaran Islam khususnya dalam pandangan Aisyiyah maupun Muhammadiyah itu kurang makruf. Karena memang menikah dini apalagi di usia anak tentu jiwa, pikiran, serta orangnya belum mencukupi, belum dewasa, belum kuat untuk mengemban tugas yang tidak sederhana di dalam konteks pernikahan.

Faktor-Faktor yang Mendorong Terjadinya Perkawinan Dini di Yogyakarta

Banyak faktor yang memicu perkawinan dini, baik dari aspek ekonomi, pendidikan, budaya dan lainnya. Berdasarkan hasil wawancara dengan TDS (DS, 2019) usia 16 tahun, salah satu pasangan perkawinan dini yang dilakukan 14 Juni 2019 di tempat tinggalnya didapatkan informasi bahwa informan melakukan pernikahan dini dikarenakan efek dari pergaulan bebas yaitu hamil pra nikah. Terjadinya hamil di luar nikah, karena anak melakukan hubungan yang melanggar norma, memaksa mereka untuk melakukan perkawinan dini, guna memperjelas status anak yang dikandung. Perkawinan ini memaksa mereka kawin dan bertanggung jawab untuk berperan sebagai suami istri serta menjadi ayah dan ibu, sehingga hal ini akan berdampak dengan penuaan dini, karena mereka belum siap lahir dan batin. Di samping itu, dengan kehamilan di luar nikah dan ketakutan orang tua akan hamil di luar nikah mendorong anaknya untuk menikah di usia yang masih belia.
Sumber informasi utama yang didapatkan dari wawancara mendalam ternyata salah satu faktor adanya fenomena oernikahan diini karena kehamilan pra nikah. Kurangnya pengetahuan tentang penddikan agama, formal dan norma- norma sosial menjadi sebab lainnya. Pada umumnya pengetahuan agama yang mereka dapatkan hanyalah semasa SD/MI, salama mereka masih duduk di bangku sekolah dasar dan sederajat, setiap sore mereka juga mendapatkan pendidikan agama dari TPA di masjid-masjid terdekat, namun hal ini tidak berlanjut ketika mereka menginjak usia SMP atau sederajat, selain itu TPA hanya menekankan bagaimana tata cara membaca Al-Qur'an. Sementara pengetahuan tentang hukum-hukum islam terutama dalam ilmu Fiqh belum mendapatkan. Ditambah keterbatasan orang tua dalam memberikan pemahaman tentang pentingnya pendidikan agama dan normanorma sosial. Dari keterbatasan itulah pasangan ini melakukan hubungan yang dilarang agama dan norma - norma yang ada.

Informan kedua (ADM), usia 16 tahun, MDM, usia 15 tahun, dan MAS, usia 15 tahun juga didapatkan informasi yang hampir sama. Faktor utama informan melakukan pernikahan dini adalah karena tidak mempunyai bekal pendidikan yang cukup tentang pernikahan dan khususnya pendidikan agama sebagai benteng dalam menjaga normanorma. Karena kebebasan dalam pergaulan dan kurangnya perhatian orang tua menjadi kan mereka menganggap bahwa pergaulan itu adalah lazim dan dianggap biasa di jaman sekarang.

Berdasarkan karakter dan hasil informasi yang sama, maka infromasi yang didapatkan ini sudah dianggap cukup untuk mendasarkan kesimpulan bahwa faktor pendidikan, khususnya pendidikan agama menjadi faktor utama dalam penyebab munculnya pernikahan dini. Sementara faktor ekonomi muncul akibat adanya pernikahan dini, dengan kata lain faktor ekonomi muncul setelah adanya pernikahan dini. Faktor ini yang menjadikan penyebab terbesar munculnya perceraian, karena ketidak siapan mereka dalam memenuhi kebutuhan sehari hari. Sementara faktor budaya yang dulu 
dianggap sebagai faktor yang penting juga, berdasarkan hasil temuan tidak begitu berpengaruh. Faktor budaya dalam hal ini adalah adanya anggapan bahwa anak perempuan yang tua nanti tidak dapat mendapatkan jodoh.

\section{Hubungan pernikahan dini dikaitkan dengan pendidikan agama}

Dalam pendidikan Islam, masalah perkawinan diatur dengan baik dan sempurna. Ada syarat-syarat yang harus yang harus dipenuhi sebelum berlangsungnya pernikahan yaitu kesiapan umur, mental, dan ekonomi. Untuk menyiapkan syarat tersebut memerlukan pengetahuan yang cukup. Sementara untuk mendapatkan pengetahuan perlu mendapatkan pendidikan yang layak dan cukup. Dengan pendidikan yang cukup calon pasangan akan mengetahui bagaimana hak dan kewajiban sebagai suami dan istri baik secara batin dan lahir

Untuk meminimalisir terjadinya pernikahan dini, maka sangat di sarankan faktor pendidikan di utamakan. Orang tua sebagai lingkungan terkecil dlam masyarakat mempunyai kewajiban mendorong anaknya untuk sekolah setinggi- tingginya. Selain itu, pendidikan agama perlu di berikan sebagai bagian dalam membentuk karakter yang baik dari anak. Pendidikan agama menjadi penjaga moral dari anak. Pengetahuan yang baik dalam bidang agama minimal akan menjadikan anak dapat memilah dan memilih sesuatu yang baik. Sesuatu yang dianggap haram dan tidak diperbolehkan dalam norma- norma yang ada di masyarakat.

Pemerintah juga mempunyai tanggung jawab untuk memberikan pendidikan secara umum kepada masyarakat. Salah satunya dengan memberikan penyuluhan be kerja sama dengan pemuka agama dan juga orang tua memberikan pemahaman keislaman persoalan perkawinan sesuai dengan syariat dan ajaran agama Islam.

\section{PENUTUP}

Berdasarkan hasil analisis data dan temuannya dapat disimpulkan bahwa fenomena pernikahan dini di daerah Yogyakarta ternyata di sebabkan karena faktor rendahnya tingkat pendidikan, minimnya wawasan agama, dan pergaulan sosial yang sangat bebas. Pasangan pernikahan dini, tidak banyak mengetahui sebelumnya tentang batasan dalam pergaulan dan perkawinan. Hal ini juga disebabkan karena faktor pendidikan yang rendah. Rata - rata berpendidikan SD dan SMP.

Dengan bekal pendidikan yang masih kurang sudah tentu mereka tidak dapat berpikir secara komprehensif tentang adanya pernikahan. Pernikahan dilangsungkan karena keterpaksaan dengan adanya kasus kehamilan pra nikah.

Maraknya pernikahan dini ini juga mengakibatkan dampak terhadap perceraian yang tinggi. Ketidakmampuan dalam mengarungi bahtera rumah tangga karena ketidaksiapan dari aspek pengetahuan (agama dan umum), mental, ekonomi, status sosial menjadi faktor terbesar terjadinya perceraian dini.

\section{UCAPAN TERIMA KASIH}

Artikel ini terwujud tidak lepas dari bantuan banyak pihak. Penulis mengucapkan terima kasih kepada pihak terkait, terutama kepada kepala KUA Kotagede, tokoh masyarakat, dan informan utama yang telah memberikan informasi dan data yang akurat tentang tema yang diteliti. Tak lupa penulis juga mengucapkan banyak terima kasih sebesar-besarnya kepada pimpinan redaksi dan seluruh tim jurnal Al-Qalam Balai Litbang Makassar yang telah berkenan memberikan ruang dan tempat dalam penerbitan artikel penelitian yang sudah dilakukan penulis.

\section{DAFTAR PUSTAKA}

Agama RI, D. (2010). Al-Qur'an dan Terjemahnya. Bandung: $\mathrm{CV}$. Diponegoro.

Burhan, S. (2005). Ijinkan Aku Menikah Tanpa Pacaran. Solo: Barokah Belia.

Creswell, J. (2015). Penelitian kualitatif \& Desain riset, memilih antara lima pendekatan. Yogyakarta: Pustaka Pelajar. 
Dika Setyaningrum, T. (2019). Alasan melakukan Pernikahan Dini (No. 1). Retrieved from 14.00.

DS, T. (2019). Alasan melakukan Pernikahan Dini (No. 1). Retrieved from 14.00.

Ghazaly, A. (2003). Fiqh Munakahat. Jakarta: Prenada Media.

Mahfudz, J. (2001). Psikologi Anak dan Remaja Muslim. Jakarta: Pustaka Al Kautsar.

Marimba, A. (1992). Pengantar Filsafat Pendidikan Islam. Bandung: Al M'arif.

Masngudi, M. (2017). Pernikahan Usia Dini; Faktor dan Implikasi Perspektif Hukum Islam. IAIN Salatiga, Salatiga.

Masngudi, Muhammad. (2017). Pernikahan Usia Dini; Faktor dan Implikasi Perspektif Hukum Islam. IAIN SALATIGA, Salatiga.

Ramulyo, M. (2002). Hukum Perkawinan Islam. Jakarta: Bumi Aksara.

Suara Muhammadiyah, S. M. (2019, March 1). Pro Kontra Pernikahan Dini. Suara Muhammadiyah. p. 9.

Sudarsono, S. (1992). Hukum Perkawinan Nasional. Jakarta: UI Press.

Sugiyono, S. (2015). Metode penelitian pendidikan, pendekatan kuantitatif, kualitatifdan R \& D. Bandung: Alfabeta.

Supriyono, S. (2019). Pandangan tentang Pernikahan Dini (No. 2). Retrieved from 10.00 .

Surahman, S. (2019). Pernikahan Dini dalam perspektif Agama (No. 4). Retrieved from 15.22.

Wahyu, W. (2019). Pernikahan Dini dalam perspektif Agama (No. 3). Retrieved from 13.00.

Wahyudi, A. (2010). Nikah Dini. Sukoharjo: Alfata. 
